\title{
Ecological Retaining Wall for High-Steep Slopes: A Case Study in the Ji-Lai Expressway, Eastern China
}

\author{
Peng Jiang $\mathbb{D}^{1},{ }^{1}$ Jin Li $\mathbb{D}^{1},{ }^{1}$ Shen Zuo, ${ }^{1}$ and Xin Zhuang Cui $\mathbb{D}^{2}$ \\ ${ }^{1}$ School of Civil Engineering, Shandong Jiaotong University, Jinan 250357, China \\ ${ }^{2}$ School of Civil Engineering, Shandong University, Jinan 250061, China \\ Correspondence should be addressed to Jin Li; sdzblijin@163.com
}

Received 4 February 2020; Revised 16 May 2020; Accepted 16 June 2020; Published 24 July 2020

Academic Editor: Xuzhen He

Copyright ( 2020 Peng Jiang et al. This is an open access article distributed under the Creative Commons Attribution License, which permits unrestricted use, distribution, and reproduction in any medium, provided the original work is properly cited.

\begin{abstract}
Research on the retaining structures for high-steep slopes is extremely significant because of its real-world applications and farreaching implications. A flexible geocell-reinforced ecological retaining wall as a high-steep slope protection scheme was developed and applied to the slope protection project of the Ji-Lai Expressway by analyzing the reinforcement mechanism of the geocell used. The lateral displacement and Earth pressure distribution on the flexible ecological retaining wall applied to the highsteep slope were studied using finite element numerical simulations and verified using field experiments. Results reveal that the wall maximum horizontal displacement is $2 / 3 \mathrm{H}$ away from the wall toe because of the replacement of the upper part of soil. There is an obvious bucking effect on the active Earth pressure around the stiffened site, and the flexible deformation of the retaining wall helped effectively release some of the Earth pressure. Consequently, the measured value is lower than the theoretical value. Through this case study, it is demonstrated that the flexible ecological retaining wall as a slope protection technology can be successfully applied to steep slopes with a height of more than $15 \mathrm{~m}$. Moreover, it brings significant advantages for protecting the ecological environment and improving the highway landscape.
\end{abstract}

\section{Introduction}

High-grade highway slopes are built in the process of filling embankments or during excavations to improve highway networks. To stabilize such slopes, surface protection measures are implemented, such as grout coating, concrete coating, and mortar rubble coating, and common measures, such as flexible retaining walls and rigid retaining walls, are applied to retain a reinforced structure $[1,2]$.

Many types of rigid retaining walls have been employed to retain stabilization of slope, including cantilever retaining walls and gravity retaining walls. To promote the application of dry-stone walling to current civil engineering practices, Colas et al. [3] conducted a failure test on a full-scale model, validated and calibrated a yield design model, and evaluated the stability of a dry-stone retaining wall. However, from the perspective of building materials and methods, the technical requirements for such structures are less, and practical applications are bound to have some limitations. Choi et al. [4] and Saim and Kasa [5], respectively, conducted experimental tests and numerical simulations on a T-shaped cantilever retaining wall and studied its displacement mode and stress state. Limited by its height, the T-shaped cantilever retaining wall could not contribute to the protection of the high-steep slopes. By conducting a scale model test, Zhu et al. [6] studied the factors influencing the deformation mode of a gravity retaining wall and the failure mode of footings made of different materials. Liu et al. [7] employed the pseudostatic method and limit equilibrium method to study the effect of embedded depth on the critical acceleration of a soil-wall system and quantified the seismic rotational stability of a gravity retaining wall. They showed that the embedded depth of the footing significantly influences the stability of the wall: they emphasized on using a deep footing for gravity retaining walls intended for high-steep slope protection. Clearly, a rigid retaining wall is unsuitable 
for protecting high-steep slopes because of certain limitations like the self-weight effect, deep footing, high structural requirements, and huge construction cost.

Methods for slope protection are usually detrimental to the original vegetation and restoration efforts, resulting in a significant amount of secondary bare land, and the subsequent rainfall and runoff energy can lead to soil erosion and, in some cases, slope collapse [8], which will further degrade the ecosystem. Vegetation significantly affects the hydrological and mechanical properties of hill slopes, which are conducive to the long-term stability of the slope ecosystem [9]. Sanchez-Castillo et al. [10] concluded that in addition to studying the technical factors of plants as structural components, the ecological and morphological characteristics of the different species and the adaptation of plants to the disturbance should be considered. Based on the limit equilibrium principle, Bischetti et al. [11] improved the existing mechanical model that provided the coefficient of safety for a specific slope, quantifying the effect of brush layering on slope stability. Yan et al. [12] defined the concept of original ecological tridimensional slope vegetation and studied the slope fixation mechanism of vegetation by performing a theoretical and observational analysis and a comparison of tridimensional slope vegetation in the wild.

From the perspective of protecting the ecological environment, enhancing the highway landscape, and maintaining an ecological balance, the application of soil bioengineering technologies should be encouraged. Cao et al. [13] adopted air bricks for slope protection, where the holes in the air bricks were filled with vegetation, providing a good example for increasing vegetation cover through ecological engineering. However, the transportation of air bricks is inconvenient because of their overall weak structure, and there remain many limitations for steep slope protection. Compared with air bricks, geocells not only provide space for planting vegetation, thereby improving the amenity values of the surrounding environment, but also conform to the terrain owing to their flexibility, convenient transportation, and construction scheme. Barring the effect of plant solidification, the confinement of a three-dimensional (3D) geocell itself can improve the bearing capacity of soil and prevent soil erosion $[14,15]$.

Flexible geocell-reinforced retaining walls have drawn considerable research attention in recent years. Currently, the stability of such walls can be studied using methods such as field monitoring, centrifugal model testing [16], and theoretical simulation and calculation [17]. Pokharel et al. [18] experimentally studied the factors influencing the stiffness and bearing capacity of single geocell-reinforced retaining walls. Chen and Chiu [19] carried out a model test to analyze the reinforcement action and the failure mechanism under an overload. Leshchinsky et al. [20] analyzed the slip surfaces of geocell-reinforced retaining walls through shaking table tests and recommended the equivalent pseudostatic coefficients in the earthquake-resistant design of reinforced retaining walls. By conducting centrifuge model tests, Song et al. [21] found that the failure mechanisms of geocell-reinforced retaining walls were similar to those of slopes.
Clearly, many studies have been conducted on the stability of geocell-reinforced retaining walls under various simulated loads. However, there are some gaps between practical application and theoretical analysis with respect to geocell-reinforced retaining walls under different geological conditions; the study of the effects of lateral Earth pressure and displacement distribution might as well be regarded as an important research topic. In this study, based on a structural analysis and finite element numerical simulation of a geocell-reinforced retaining wall, a high-steep slope protection scheme is applied to a highway slope of the Ji-Lai Expressway. The simulation results were verified using field test monitoring data, and the lateral Earth pressure and displacement distribution were studied. These results can serve as a basis for further research on geocell-reinforced retaining walls as a highway slope protection scheme.

\section{Scheme Comparison}

2.1. Project Background. The section of the Ji-Lai Expressway that was evaluated is located on the second-level terrace of a river valley. The slope of the terrace is nearly vertical, and the height of the terrace is in the range of $15.47-16.94 \mathrm{~m}$ (Figure 1(a)). The foundation soil is Q3 collapsible loess. It is common knowledge that loess with some typical internal structure is found to be more stable than common soil; however, a field survey has pointed to the presence of cracks in this soil layer, causing some damage to the subgrade. Penetrating longitudinal cracks over $3 \mathrm{~m}$ wide can be observed on the roadbed surface, as shown in Figure 1(b). The edge of the roadbed has collapsed, and some transverse cracks have intruded $0.92 \mathrm{~m}$ along the roadbed. Any highway engineering project performed near this geological structure could seriously affect the stability of the embankment.

2.2. Retaining Wall Scheme. To eliminate hidden dangers and ensure highway engineering quality and driving safety, the necessary engineering measures for slope protection need to be evaluated. The commonly used rigid gravity retaining wall scheme was voted down for the following reasons at the early stage of this project: (1) the JTG D302004 Specifications for Design of Highway Subgrades [22] state that gravity masonry retaining walls should not exceed a height of $12 \mathrm{~m}$; considering the embedded depth of the footing and main body structure, the wall height of a gravity masonry retaining wall would exceed $18 \mathrm{~m}$, which is far beyond the specified value; (2) the heavy weight of masonry retaining walls has more requirements in terms of construction technology; hence, there will be no space for ecological greening; (3) in engineering practice, the construction cost is a key factor that should be considered. The estimated construction cost based on earthwork processing, material cost, and foundation treatment is approximately 763,000 yuan.

An ecological geocell-reinforced retaining wall scheme was proposed owing to the following reasons: (1) a geocellreinforced retaining wall is lighter than a masonry structure, 


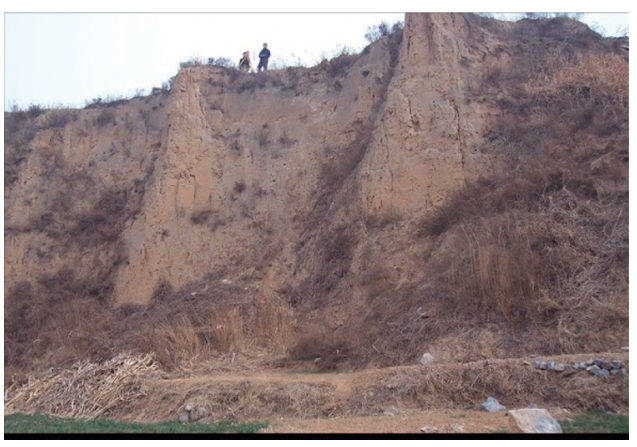

(a)

Figure 1: Actual geological site. (a) Terrain. (b) Longitudinal crack at the top of roadbed.

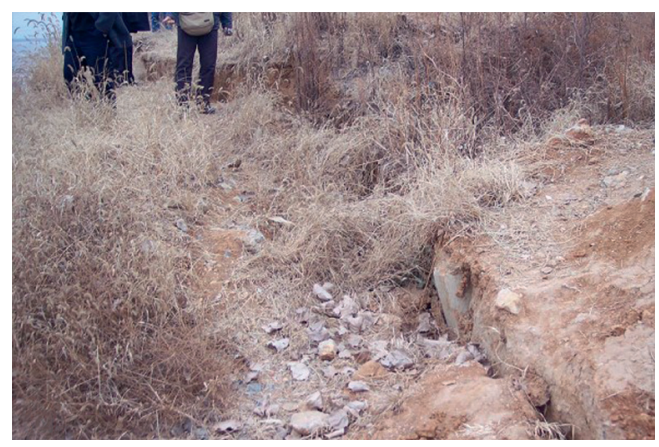

(b) with only minor foundation treatment required, and the structural damage to the retaining wall due to the uneven settlement of the footing can be avoided; (2) the vegetation cover around the geocell on the retaining wall surface can help resist soil erosion and slope instability, which plays a role in afforestation; (3) the construction cost is relatively low, with the estimated construction cost based on earthwork processing, material cost, and foundation treatment being approximately 542,000 yuan.

Given the many advantages of flexible geocell-reinforced retaining walls, the construction scheme is determined as follows. The main structure is divided into two parts: a $3 \mathrm{~m}$ high lower part resting on a $4.8 \mathrm{~m}$ wide mortar rubble footing and a $12 \mathrm{~m}$ high upper part resting on a $4 \mathrm{~m}$ wide geocell-reinforced retaining wall with a slope gradient of 1 : 0.5 . Moreover, above the retaining wall is a $3 \mathrm{~m}$ high filling slope with a gradient of $1: 1.5$. Figure 2 shows the retaining wall structure in greater detail.

2.3. Reinforcement Mechanism. Studying the reinforcement mechanism of geocells is conducive for practical engineering applications. Under the action of the upper load, the geocell wall provides a good lateral restraint, which is controlled by the tensile strength of the geocell material. The volume of the geocell is assumed to remain unchanged, and according to the rubber membrane theory proposed by Henkel and Gilbert [23], the additional confining pressure $\sigma^{*}$ due to the membrane stresses can be expressed as

$$
\sigma^{*}=\frac{2 M}{d_{0}}\left(\frac{1-\sqrt{1-\varepsilon_{0}}}{1-\varepsilon_{0}}\right),
$$

where $M$ is geocell material modulus, [MPa], $d_{0}$ is initial diameter of an individual geocell pocket, [m], and $\varepsilon_{0}$ is geocell allowable axial strain.

Under this pressure, anchorage (or interfacial friction, or both) is imposed by the geocell walls (Figure 3 ). Thus, the geocell comprehensively behaves as a semirigid composite slab with the surrounding soil. The reinforced layer forms a concave surface under the action of the upper load, and the pressure $P$ on the concave surface is greater than the pressure $P_{b}$ beneath the concave surface, thus generating a net effect. The equivalent modulus $E^{*}$ of a semirigid composite slab is improved by the geocell, according to the principle of deformation equivalence:

$$
\frac{P}{E^{*}}=\frac{P-P_{s}}{E} \Rightarrow E^{*}=E \frac{P}{P-P_{s}},
$$

where $E$ is soil deformation modulus $(\mathrm{MPa})$ and $P_{s}$ is upward stress provided by the geocell wall $(\mathrm{kPa})$.

Through the net effect and owing to the slab configuration, the upper load is uniformly redistributed to a wider area, with a lower intensity to improve the load-bearing capacity of the soil, and to a certain extent, the differential settlement under the action of the upper load is effectively resisted [24, 25].

The apparent cohesion of sand, even of dry sand, is close to zero. A geocell induces a significant apparent cohesion on the infilled soil [26], and the walls cut the potential slip surface (Figure 4), which develops in an unreinforced condition and forces it to go deeper into the soil, thereby increasing the stability and bearing capacity of the soil $[16,27]$. To summarize, the mechanism of geocell reinforcement can be interpreted as "confinement," "membrane action," and "stress distribution" $[25,28]$.

The above qualitative analysis demonstrates that the geocell helps improve the lateral constraint on the reinforced soil, and the deformation of the soil is decreased. In addition, owing to the lifting force of the geocell, the deformation of the lower part of the soil is reduced. In fact, the overall role of the geocell in the subgrade is much more complex. To apply and verify the above reinforcement theory in engineering practice, several indoor and outdoor tests should be conducted to accumulate the measurement data.

\section{Materials and Methods}

\subsection{Theoretical Calculation}

3.1.1. Physical Parameters. The main physical and mechanical properties of the loess in the section of the Ji-Lai Expressway taken as the test case should be determined, which is conducive to the theoretical calculation, numerical simulation, and practical engineering application (Figure 5). In accordance with the JTG E40-2007 Test Methods of Soils for Highway Engineering [29], the loess was subjected to a 


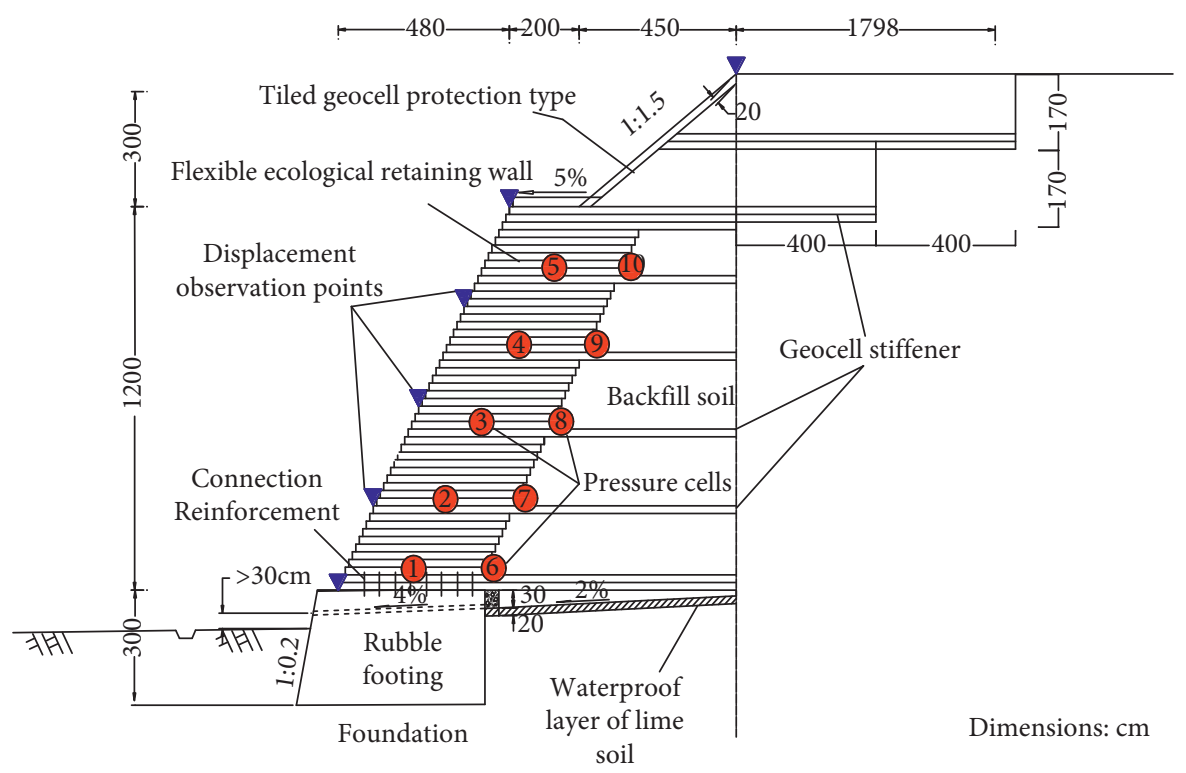

FIGURE 2: Design of a slope protection scheme and layout of test elements.

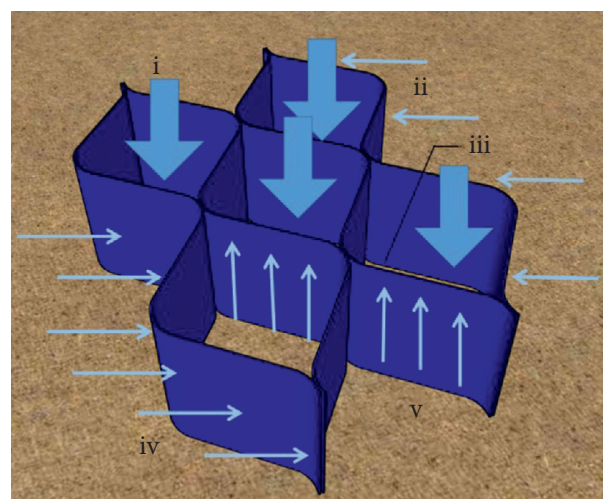

Figure 3: Configuration of a geocell. Reinforcement mechanism of a geocell. (i) Upper load, (ii) geocell wall, (iii) infilled soil, (iv) lateral restraint, and (v) anchorage or interfacial friction or both.

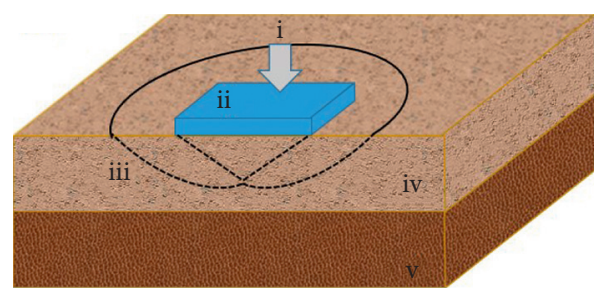

(a)

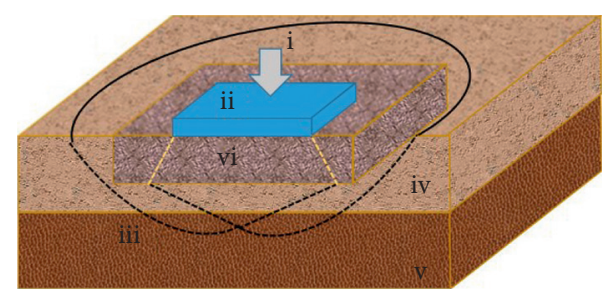

(b)

FIGURE 4: Development of slip surfaces in unreinforced and geocell-reinforced foundations. (a) Unreinforced foundation: (i) upper load, (ii) footing, (iii) failure surface, (iv) sand, and (v) clay. (b) Geocell-reinforced foundation: (vi) geocell layer.

number of tests, namely, plastic limit, liquid limit, compaction, compression, shear, and particle analysis tests. A repeatability test helps control the error, and the test data are recorded. Test results are listed in Table 1. The geocell specifications are listed in Table 2.

The following assumptions are made before conducting the theoretical calculation and analysis: (a) There are $n$ layers of geocell stiffeners with a spacing of $x(\mathrm{~m})$, and the anchorage zone length $L_{m}(\mathrm{~m})$ of each layer is equal.

(b) The anchorage zone containing the geocell stiffener is considered a uniform equivalent zone, and $f^{*}$ is the pull friction coefficient between the geocell stiffener and the backfill. 


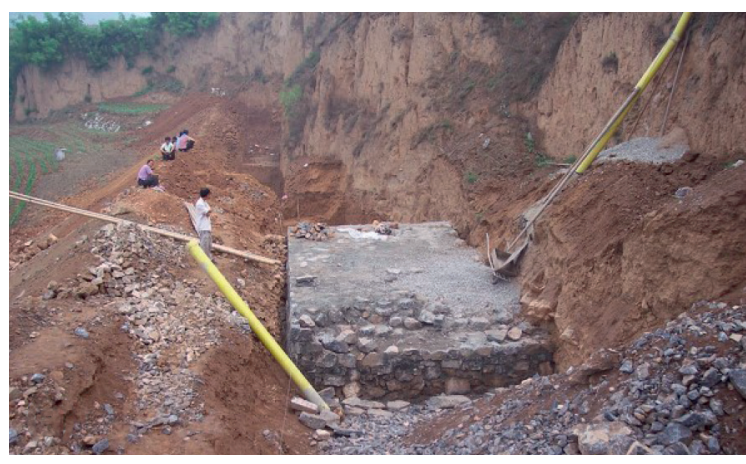

(a)

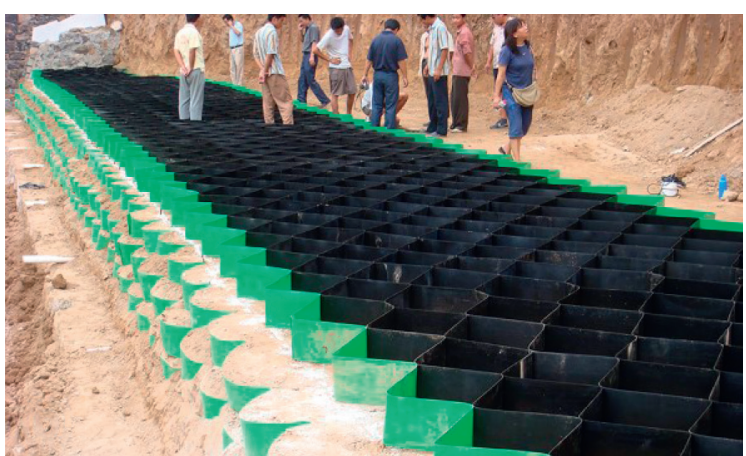

(b)

Figure 5: Construction of an ecological retaining wall. (a) Mortar rubble masonry footing. (b) Geocell-reinforced retaining wall.

TABLE 1: Subsoil main properties.

\begin{tabular}{|c|c|c|c|c|c|c|c|c|}
\hline \multirow[b]{2}{*}{$\begin{array}{l}\text { Sampling } \\
\text { depth }(\mathrm{m})\end{array}$} & \multirow[b]{2}{*}{$\begin{array}{c}\text { Water } \\
\text { content }(\%)\end{array}$} & \multirow[b]{2}{*}{$\begin{array}{l}\text { Dry density } \\
\left(\mathrm{g} \cdot \mathrm{cm}^{-3}\right)\end{array}$} & \multirow[b]{2}{*}{$\begin{array}{l}\text { Void } \\
\text { ratio }\end{array}$} & \multicolumn{2}{|c|}{$\begin{array}{c}\text { Peak strength of } \\
\text { consolidated quick shear }\end{array}$} & \multirow[b]{2}{*}{$\begin{array}{l}\text { Strength of vane } \\
\text { shear test }(\mathrm{kPa})\end{array}$} & \multicolumn{2}{|c|}{ Heavy compaction test } \\
\hline & & & & $\begin{array}{l}\text { Friction } \\
\text { angle }\left({ }^{\circ}\right)\end{array}$ & $\begin{array}{l}\text { Cohesion } \\
(\mathrm{kPa})\end{array}$ & & $\begin{array}{c}\text { Optimum } \\
\text { moisture content } \\
(\%)\end{array}$ & $\begin{array}{l}\text { Maximum dry bulk } \\
\text { density }\left(\mathrm{kg} \cdot \mathrm{m}^{-3}\right)\end{array}$ \\
\hline 5 & 2.9 & 1.41 & 0.93 & 17.6 & 34 & 34.6 & 14.7 & 19.1 \\
\hline 10 & 15 & 1.47 & 0.81 & 22.4 & 34 & 36.1 & 14.7 & 19.3 \\
\hline 15 & 4.3 & 1.50 & 0.74 & 25.4 & 38 & 39.2 & 14.6 & 19.3 \\
\hline
\end{tabular}

TABLE 2: Geocell specifications.

\begin{tabular}{lccccc}
\hline $\begin{array}{l}\text { Thickness of } \\
\text { geocell wall }(\mathrm{mm})\end{array}$ & $\begin{array}{c}\text { Soldering } \\
\text { distance }(\mathrm{mm})\end{array}$ & $\begin{array}{c}\text { Height of } \\
\text { geocell wall } \\
(\mathrm{mm})\end{array}$ & $\begin{array}{c}\text { Low-temperature } \\
\text { brittleness }\left({ }^{\circ} \mathrm{C}\right)\end{array}$ & $\begin{array}{c}\text { Tensile yield } \\
\text { strength }(\mathrm{MPa})\end{array}$ & $\begin{array}{c}\text { Vicat softening } \\
\text { point }\left({ }^{\circ} \mathrm{C}\right)\end{array}$ \\
\hline $1.2 \pm 0.1$ & 680 & 150 & -50 & 24.3 & 114.7 \\
\hline
\end{tabular}

(c) The tension design value of each layer is determined by the pullout resistance $T_{i}(\mathrm{kN})$ of the geocell stiffener, where $i$ is the number of layers. The pullout resistance can be calculated as follows:

$T_{i}=\frac{S_{i}}{\left[K_{f}\right]}=\frac{2 \gamma(i-1) x f^{*} L_{m}}{\left[K_{f}\right]}, \quad i=1,2, \ldots, n$,

where $S_{i}$ is ultimate pullout capacity of the $i$ th layer $(\mathrm{kN}) ; \gamma$ is bulk density of the backfill $\left(\mathrm{kN} \cdot \mathrm{m}^{-3}\right)$; and $\left[K_{f}\right]$ is dimensionless safety coefficient for pullout stability.

(d) The filling slope gravity and vehicle load acting on the retaining wall are converted to the equivalent soil layer thickness $h(\mathrm{~m})$ :

$$
h=h_{1}+\frac{\sum G_{v}}{B_{v} L_{0} \gamma}
$$

where $h_{1}$ is filling slope height above the retaining wall $[\mathrm{m}] ; B_{v}$ and $L_{0}$ are load arrangement length and width, respectively $(\mathrm{m})$ (the width of subgrade); and $\sum G_{v}$ is wheel load or crawler load acting in the area of $B_{y} L_{0}(\mathrm{kN})$.
The Earth pressure $E a(\mathrm{kN})$ acting at the back of the retaining wall and the height of the net force working point $H_{E_{a}}(\mathrm{~m})$ are calculated as follows:

$$
\begin{aligned}
E_{a} & =\frac{h+(H+h)}{2} \gamma H K_{\mathrm{a}}=\frac{\gamma H K_{\mathrm{a}}(2 h+H)}{2} \\
H_{E_{a}} & =\frac{(1 / 2) H^{2} \gamma h K_{a}+(H / 2)(H / 3) \gamma H K_{a}}{(H / 2) \gamma(H+2 h) K_{a}}=\frac{H(H+3 h)}{3(H+2 h)},
\end{aligned}
$$

where $K_{a}$ is the dimensionless coefficient of the active Rankin pressure, $K_{a}=\cos ^{2}(\varphi-\alpha) / \cos ^{2} \alpha \cos (\delta+\alpha)$ $[1+\sqrt{\sin (\varphi+\delta) \sin \varphi / \cos (\delta+\alpha) \cos \alpha}]^{2} ; \delta$ is friction angle at the back of the retaining wall $\left(^{\circ}\right) ; \alpha$ is retaining wall inclination $\left({ }^{\circ}\right) ; \varphi$ is geocell soil internal friction angle $\left({ }^{\circ}\right)$; and $H$ is retaining wall height $(\mathrm{m})$.

3.1.2. Feasibility Analysis. The stability of the retaining wall should be analyzed considering the resistance provided by the retaining wall itself and the resistance of the geocell stiffener. Figure 6 shows the theoretical calculation schematic applied to the flexible retaining wall.

(1) Analysis of antislip stability: 


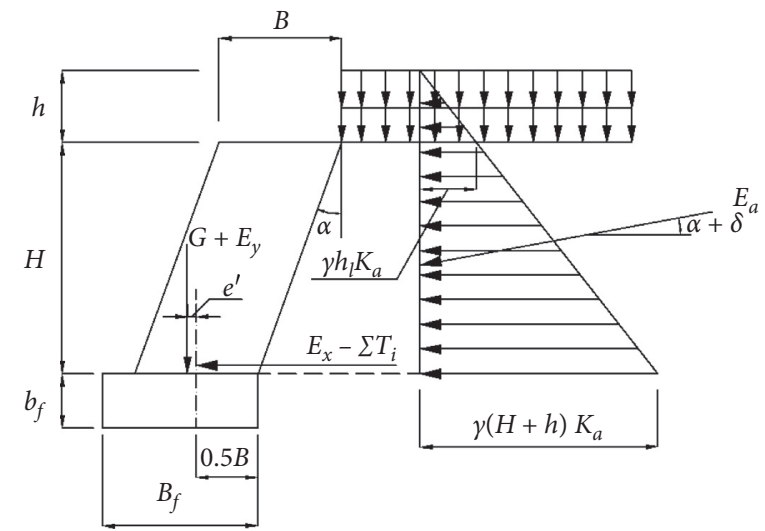

Figure 6: Theoretical calculation of the flexible retaining wall.

$K_{c}=\frac{\mu N+\sum_{i=1}^{n} T_{i}}{E_{x}}=\frac{\mu\left(G+E_{y}\right)+\sum_{i=1}^{n} T_{i}}{E_{x}} \geq\left[K_{c}\right]$,

where $\mu$ is soil dimensionless Poisson's ratio; $N$ is axial force on the footing $(\mathrm{kN}) ; E_{y}, E_{x}$ are earth pressure vertical and horizontal components, respectively $(\mathrm{kN})$; and $G$ is retaining wall gravity $(\mathrm{kN})$.

(2) Analysis of antioverturning stability:

$K_{0}=\frac{\sum M_{y}}{\sum M_{0}}=\frac{G H_{G}+E_{y} H_{E_{y}}+\sum_{i=1}^{n} T_{i}(n-i+1) x}{E_{x} H_{E_{x}}} \geq\left[K_{0}\right]$, where $\sum M_{y}$ is sum of stabilizing moments of each force system to the wall toe $(\mathrm{kN} / \mathrm{m}) ; \sum M_{0}$ is sum of overturning moments of each force system to the wall toe $(\mathrm{kN} / \mathrm{m}) ; H_{E_{y}} H_{E_{x}}$ are moment arms with vertical component $E_{y}$ and horizontal component $E_{x}$ of the Earth pressure against the wall toe $(\mathrm{m})$ $\left(H_{E_{x}}=H_{E_{a}}\right) ; H_{G}$ is moment arm with retaining wall gravity $G$ against the wall toe $(\mathrm{m})$; and $\left[K_{0}\right]$ is dimensionless safety coefficient for resisting overturning.

(3) Analysis of footing eccentricity and stress:

$$
\begin{aligned}
e^{\prime} & =\frac{B}{2}-\frac{\sum M_{y}-\sum M_{0}}{N}=\frac{B}{2}-\frac{G H_{G}+E_{y} H_{E_{y}}+\sum_{i=1}^{n} T_{i}(n-i+1) x-E_{x} H_{E_{x}}}{G+E_{y}} \leq \frac{B}{6}, \\
e & =\frac{B_{f}}{2}-\frac{G_{f} B_{f} / 2+\left(G+E_{y}\right)\left(B_{f}-(B / 2)-e^{\prime}\right)-\left(E_{x}-\sum_{i=1}^{n} T_{i}\right) b_{f}}{G+E_{y}+G_{f}} \leq \frac{B_{f}}{6}, \\
\sigma_{\max } & =\frac{G+E_{y}+G_{f}}{B_{f}}+\frac{6\left(G+E_{y}+G_{f}\right) e}{B_{f}^{2}} \leq k[\sigma], \\
\sigma_{\min }= & \frac{G+E_{y}+G_{f}}{B_{f}}+\frac{6\left(G+E_{y}+G_{f}\right) e}{B_{f}^{2}} \geq 0,
\end{aligned}
$$

where $B$ is geocell-reinforced retaining wall width $(\mathrm{m})$; $\mathrm{e}^{\prime}$ is eccentricity at the retaining wall bottom $(\mathrm{m})$; e is eccentricity at the footing bottom $(\mathrm{m}) ; B_{f}$ and $b_{f}$ are footing width and height, respectively $(\mathrm{m}) ; G_{f}$ is footing gravity $(\mathrm{kN}) ; \sigma_{\max }$ and $\sigma_{\min }$ are maximum and minimum compressive stresses of the footing bottom, respectively $(\mathrm{kPa}) ; \sigma$ is revised allowable bearing capacity of the foundation soil $(\mathrm{kPa})$; and $k$ is dimensionless allowable bearing capacity improvement coefficient of the foundation soil.

The overall sliding stability of the retaining wall should be analyzed with the assumption that the geocell stiffener length should not exceed the displacement length of the sliding surface, where it may occur. The Fellenius method of slices can be used for the calculation: 


$$
K_{s}=\frac{\sum\left(c_{i} L_{i}+W_{i} \cos \alpha_{i} \tan \varphi_{i}\right)}{\sum W_{i} \sin \alpha_{i}} \geq\left[K_{s}\right]
$$

where $c_{i}, L_{i}$ are cohesion and arc length on the $i$ th block sliding surface, respectively $(\mathrm{kPa})$ and $(\mathrm{m}) ; W_{i}$ is dead weight and its applied load on the $i$ block $(\mathrm{kN}) ; \varphi_{i}$ is $i$ block soil internal friction angle $\left({ }^{\circ}\right)$; and $\alpha_{i}$ is angle between the normal and the vertical line of a sliding arc of the $i$ block $\left({ }^{\circ}\right)$.

After the calculations are made using the above formula, the flexible geocell-reinforced retaining wall scheme meets all the theoretical requirements.

\subsection{Finite Element Simulation}

3.2.1. Numerical Parameters. Backfills and retaining walls are widely regarded as ideal elastoplastic bodies and ideal linear elastomers subjected to the Mohr-Coulomb failure criterion; therefore, a constitutive model based on the Mohr-Coulomb criterion is adopted for the analysis, which can be expressed as follows:

$$
\begin{aligned}
f= & \sqrt{J_{2}}\left(\cos \theta_{\alpha}-\frac{\sin \varphi}{\sqrt{3}} \sin \theta_{\alpha}\right) \\
& +\frac{1}{3} I_{1} \sin \varphi-c \cos \varphi=0,
\end{aligned}
$$

where $J_{2}$ is the second invariant of the deviatoric stress tensor; $\theta_{\alpha}$ is lode angle $\left(-30^{\circ} \leq \theta_{\alpha} \leq 30^{\circ}\right)\left({ }^{\circ}\right)$, which is the angle between the first principal stress and the deviatoric stress component; and $I_{1}$ is the first invariant of the stress tensor. The geocell-reinforced soil triaxial compression test conducted by Chen et al. [30] indicated that reinforced soil exhibits an obvious cohesion; however, the friction angle of the reinforced soil is almost the same as that of the unreinforced soil. Therefore, the internal friction angles of the unreinforced soil and geocell-reinforced soil are assumed the same. The cohesion of geocell-reinforced soils can be estimated using an empirical equation developed by Bathurst and Karpurapu [31] and Rajagopal et al. [26] as follows:

$$
c=\frac{\sigma^{*}}{2} \sqrt{K_{p}},
$$

where $K_{p}$ is dimensionless coefficient of passive Rankin pressure; $K_{p}=\tan ^{2}((\pi / 4)+(\pi / 2))$; and $\sigma^{*}$ is additional confining pressure due to the membrane stresses in equation (1).

Furthermore, Madhavi Latha et al. [32] and Madhavi Latha and Rajagopal [33] verified the correctness of this equation. From the perspective of system engineering, the flexible ecological retaining wall, geocell stiffener, rubble footing, and backfill contribute to the maintenance of subgrade stability. They interact with each other, redistribute, and transfer stress dynamically as the load changes. A numerical simulation through ABAQUS (Dassault Systèmes 2017) can help strengthen and improve its stability design. To simplify the model and improve the computational efficiency, a two-dimensional (2D) composite model with equivalent strength and stiffness is adopted, which is accepted in the engineering community [30,34].

The calculation area is divided into several sections: flexible retaining wall, geocell stiffener, rubble footing, backfill, and foundation. Based on the physical parameters measured through laboratory testing and the feasible range of parameter values in the JTG D30-2004 Specifications of Design of Highway Subgrades [22], the numerical parameters can be determined using equation (15), which are summarized in Table 3.

\subsubsection{Simulation Model Description and Configuration.} Figure 7 shows the numerical model mesh and some of its dimensions, with different sections color-coded. The slope gradient is $1: 0.5$, and $\mathrm{H} 1$ is the height of the wall, with a value of $12 \mathrm{~m} . \mathrm{H} 2$ is the thickness of the ground base, with a value 3 times the height of the wall, which results in $36 \mathrm{~m}$. L1 is also 3 times the height of the wall $(36 \mathrm{~m})$; it allows the lateral deformation at the wall toe. L2 is $16.75 \mathrm{~m}$, which is the width of a driving lane. The mortar rubble footing is $4.8 \mathrm{~m}$ wide and $3 \mathrm{~m}$ high, and the flexible ecological retaining wall has six geocell-reinforced layers embedded in the backfill soil, with a spacing of $2.4 \mathrm{~m}$. The top layer is separated $12 \mathrm{~m}$ from the wall toe.

Horizontal displacement constraints are applied on the left and right sides of the finite element model. The vertical displacement constraints on the model are free. Horizontal and vertical displacement constraints are applied on the bottom of the model as well. The model finite elements are meshed using a structured pattern made up of high-precision four-node plane-strain quadrilateral elements.

Geocell was modeled as a 2-node linear truss element $[35,36]$. A surface-to-surface contact is employed to define the interfaces. Chen et al. [37] indicated that the interface friction angle between two geocell-reinforced sand layers is equal to the friction angle of sand because the thickness of the geocell wall was small enough. Therefore, the friction angle is specified as $25^{\circ}$. A tie constraint is set at the interfaces between the footing and foundation and between the wall and geocell [38].

In the process of nonlinear calculation, the final and most important step before applying the loads is to determine the soil initial stress state, which affects not only the initial loading calculation but also all the subsequent loading steps. This determines the success of the numerical simulation, as the stress in the subsequent loading steps is also accumulated on the basis of the previous initial stress. Considering the initial geostress balance $[39,40]$, first, the gravity load is applied to the finite element model, and the stress field calculated under the gravity load is then defined as the initial stress field and applied to the original model along with the gravity load. Thus, both the equilibrium condition and the initial stress field of the yield criterion are satisfied, and it can be ensured that the initial displacement of each node is approximately zero.

Finally, a finite element simulation is conducted after the corresponding loads (the $3 \mathrm{~m}$ high filling slope above the 
TABLe 3: Relevant numerical calculation parameters.

\begin{tabular}{lccccc}
\hline \multirow{2}{*}{ Material parameter } & & \multicolumn{2}{c}{ Analysis domain } & \\
& Flexible retaining wall & Geocell stiffener & Backfill & Foundation & Rubble footing \\
\hline Elasticity modulus $E(\mathrm{MPa})$ & 22.3 & 1600 & 22 & 25 & 2500 \\
Poisson's ratio $\mu$ & 0.3 & 0.25 & 0.35 & 0.30 & 0.22 \\
Bulk density $\gamma\left(\mathrm{kN} \cdot \mathrm{m}^{-3}\right)$ & 20 & 17 & 19.3 & 22 & 26 \\
Cohesion $C(\mathrm{kPa})$ & 60 & - & 21 & 27 & 25 \\
Friction angle $\varphi\left({ }^{\circ}\right)$ & 35 & - & 25 & 45 \\
\hline
\end{tabular}

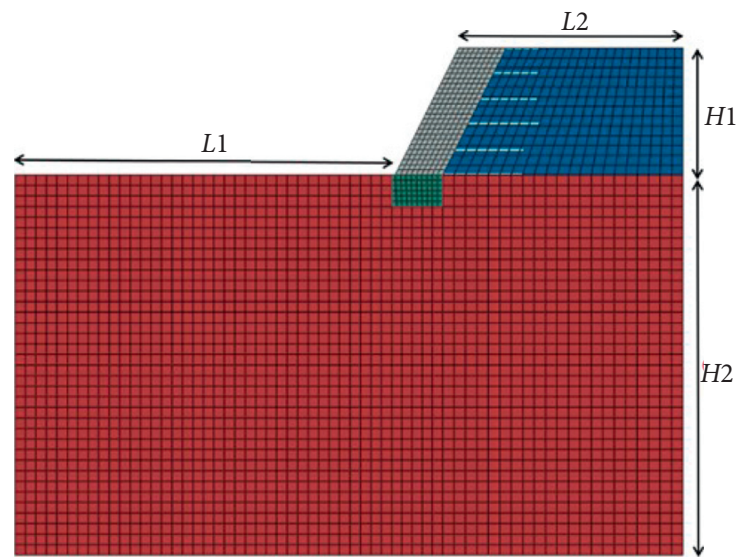

Figure 7: Numerical model mesh and size of calculation parameters.

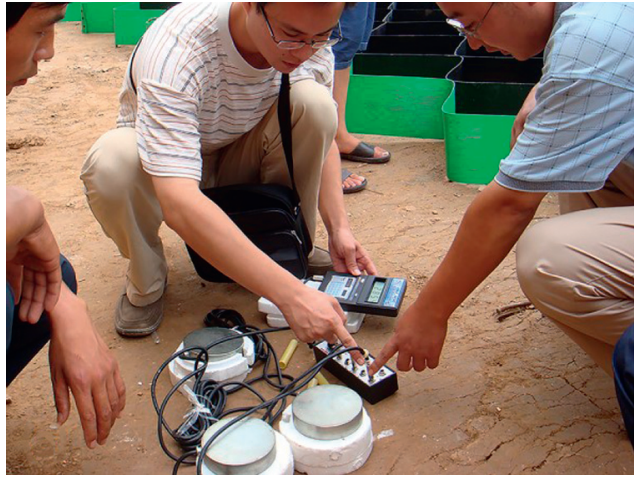

(a)

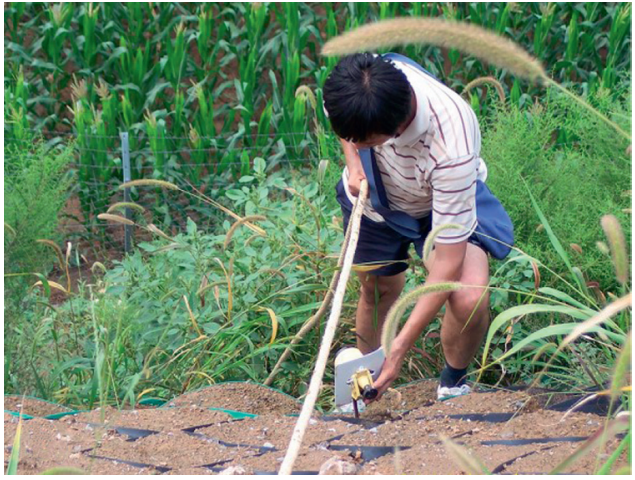

(b)

FIGURE 8: Field monitoring device. (a) Calibration of pressure cells. (b) Setting of displacement observation points.

retaining wall with a slope gradient of $1: 1.5$ is regarded as the dead load) are applied to each section.

3.3. Field Test Arrangement. The actual distribution of soil pressure and the change in the retaining wall horizontal displacement are determined to verify the numerical calculation results and obtain the working characteristics of the geocell-reinforced retaining wall in practical engineering. Based on the layout of the test elements shown in Figure 2, the pressure cells were buried at the middle and back of the flexible retaining wall, and displacement-monitoring points were laid on the surface of the retaining wall for long-term monitoring and data collection. The field monitoring device calibration and placement process is shown in Figure 8.

As shown in Figure 2, in the cross section of the flexible ecological retaining wall, $\bigcirc$ represents the buried position of the pressure cells and $\nabla$ represents the displacement observation points. Pressure cells numbers $1-5$ were embedded laterally at the middle of the wall (separated $2 \mathrm{~m}$ from the retaining wall surface); pressure cells numbers 6-10 were embedded laterally at the back of the wall (separated $4 \mathrm{~m}$ from the retaining wall surface). The displacement observation points were set at the surface of the retaining wall. 


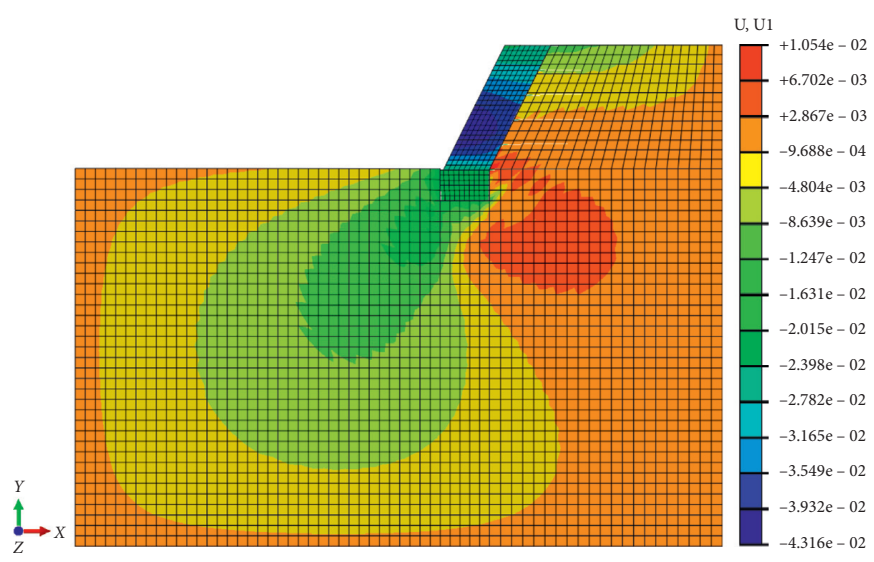

(a)

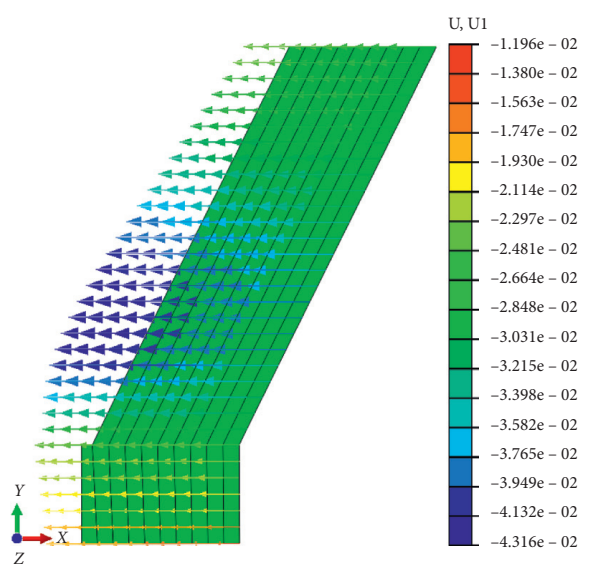

(b)

FiguRE 9: Lateral displacement distribution from numerical simulation results. (a) The geocell-reinforced retaining wall color nephogram. (b) The horizontal component of the retaining wall displacement vector.

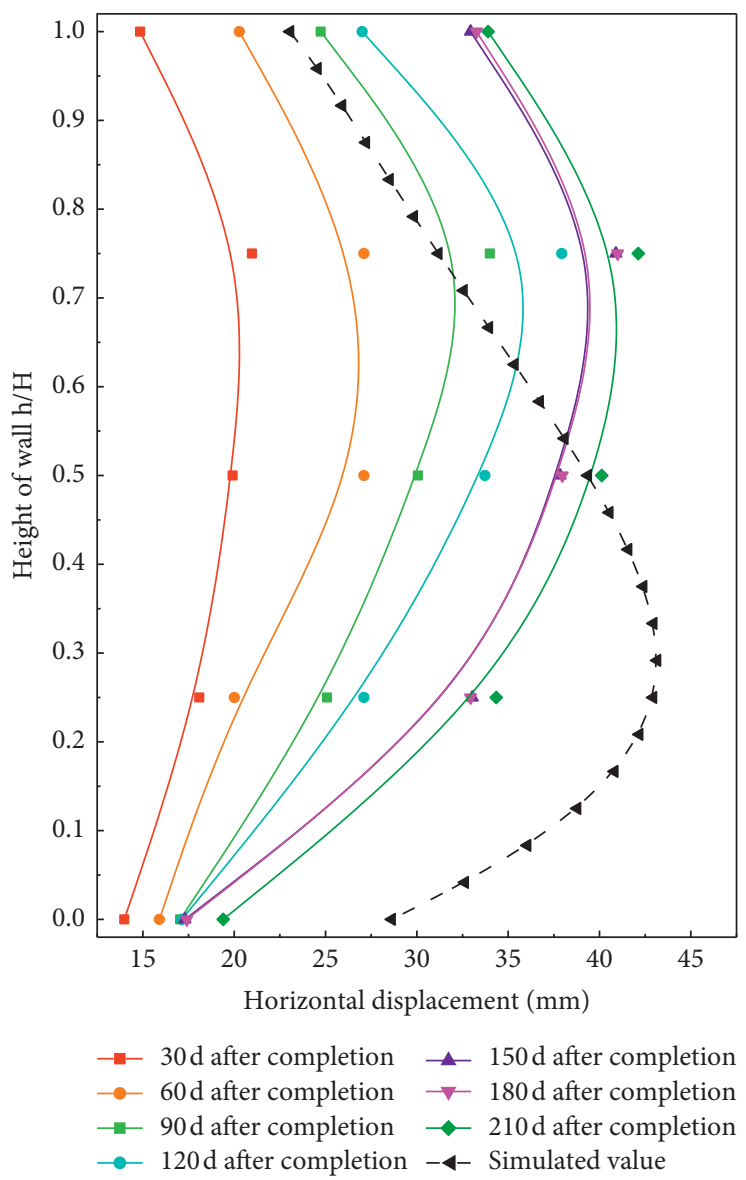

Figure 10: Measured displacement with consolidation time.

The soil pressure test results might be affected by the physical environment, construction disturbance, and quality of the test elements, resulting in a greater dispersion of the soil pressure. In this study, the value with greater dispersion was removed during the analysis of the soil pressure test results.

\section{Results and Discussion}

4.1. Lateral Displacement Analysis. Figure 9(a) shows the lateral displacement distribution obtained from the numerical model. The maximum horizontal displacement of the retaining wall is approximately $1 / 3 \mathrm{H}$ away from the wall 
toe. In the Rankine Earth pressure theory, the positive active Earth pressure of the cohesive soil is due to the dead and external loads, and the negative active Earth pressure is due to the cohesive force. According to equation (6), the net force of the active Earth pressure acts $(H(H+3 h) / 3(H+2 h))$ away from the wall toe. The horizontal component of the displacement vector of the retaining wall, described in Figure 9(b), can intuitively reflect the effect of the net force, consistent with Rankine Earth pressure theory.

Figure 10 shows the variation in measured displacement data from the field test with consolidation time: the horizontal displacement is maximum $2 / 3 \mathrm{H}$ away from the wall toe. This is because the backfill soil in the top $3 \mathrm{~m}$ range of the retaining wall was replaced by lime soil to prevent and control the existing longitudinal cracks in the actual project. Under horizontal active Earth pressure, the disturbed soil layer generates a larger horizontal deformation. Because the backfill soil behind the lower part of the retaining wall is undisturbed soil, the horizontal deformation is limited, and the deformation is the highest at the upper part, that is, approximately $2 / 3 \mathrm{H}$ away from the wall toe, while the simulated displacement is maximum approximately $1 / 3 \mathrm{H}$ away from the wall toe. This indicates that the complexity of the actual construction environment makes it difficult to evaluate the numerical parameters.

Although the flexible retaining wall could conform to larger deformation, the maximum horizontal displacement measured does not exceed $42 \mathrm{~mm}$ because the entire soil structure inside the retaining wall is not damaged. The lateral deformation due to gravity is negligible, and only small lateral deformation occurs under the action of the roadbed structure and traffic loads. Moreover, as shown in Figure 10, the deformation is stable 180 days after completion. Compared with the deformation 210 days after completion, there is little difference between them.

4.2. Lateral Soil Pressure Analysis. Figure 11 shows four selected cross section stress distribution profiles. As we move farther away from the retaining wall surface, the lateral Earth pressure along the height of the retaining wall presents more pronounced fluctuations. At the same horizontal position, the simulated value at the middle of the wall is greater than the measured value at the back of the wall (closed symbols, no line in Figure 11). This is because the geocell stiffener provides an opposite constraint, yielding a bucking effect on the active Earth pressure around the stiffened site. The closer to the stiffened site, the more obvious the restraint effect. Therefore, the measured value at the back of the wall is less than that at the middle of the wall.

The measured values at the middle and upper parts are in good agreement with the simulated value (Figure 11); however, there is a significant difference between the measured and simulated values at the lower part of the retaining wall. All the backfill behind the wall is disturbed soil in the numerical simulation. In practice, only the upper part behind the wall is disturbed soil with unstable mechanical properties, while the lower part is undisturbed soil

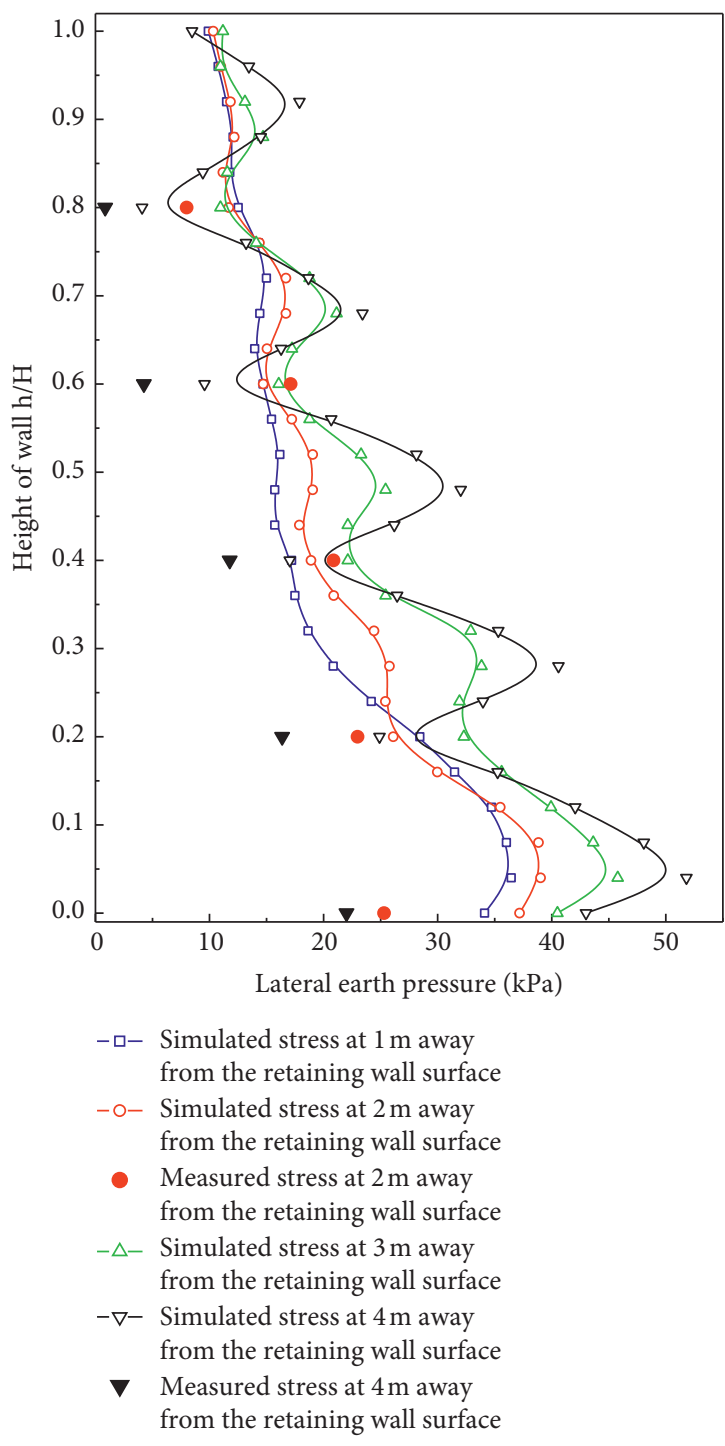

FIGURE 11: Lateral Earth pressure distribution at different cross profiles.

with undamaged natural structure and good mechanical properties. Consequently, the lateral Earth pressure is not as high as the simulated value, which is also evident from the measured value on different days after completion, as shown in Figure 12. The theoretical value of the lateral Earth pressure can be obtained using (5), and as a comparison, the measured Earth pressure is also lower than the theoretical value (see Figure 12). Because of the flexible deformation of the wall, some amount of the Earth pressure is fully released; hence, the actual lateral pressure coefficient of the backfill is lower than the theoretical value. As shown in Figure 11, the measured Earth pressure is maximum approximately $1 / 3 \mathrm{H}$ away from the wall toe, which is the height of the net force working point $H_{E_{a}}$ in the Rankine Earth pressure theory. Compared with the lateral Earth pressure 10 days after completion, the lateral Earth pressure settles more than six months after completion. This shows that under the action of load, soil consolidation is complete, and the mechanical properties of each part of the soil play a uniform role. 


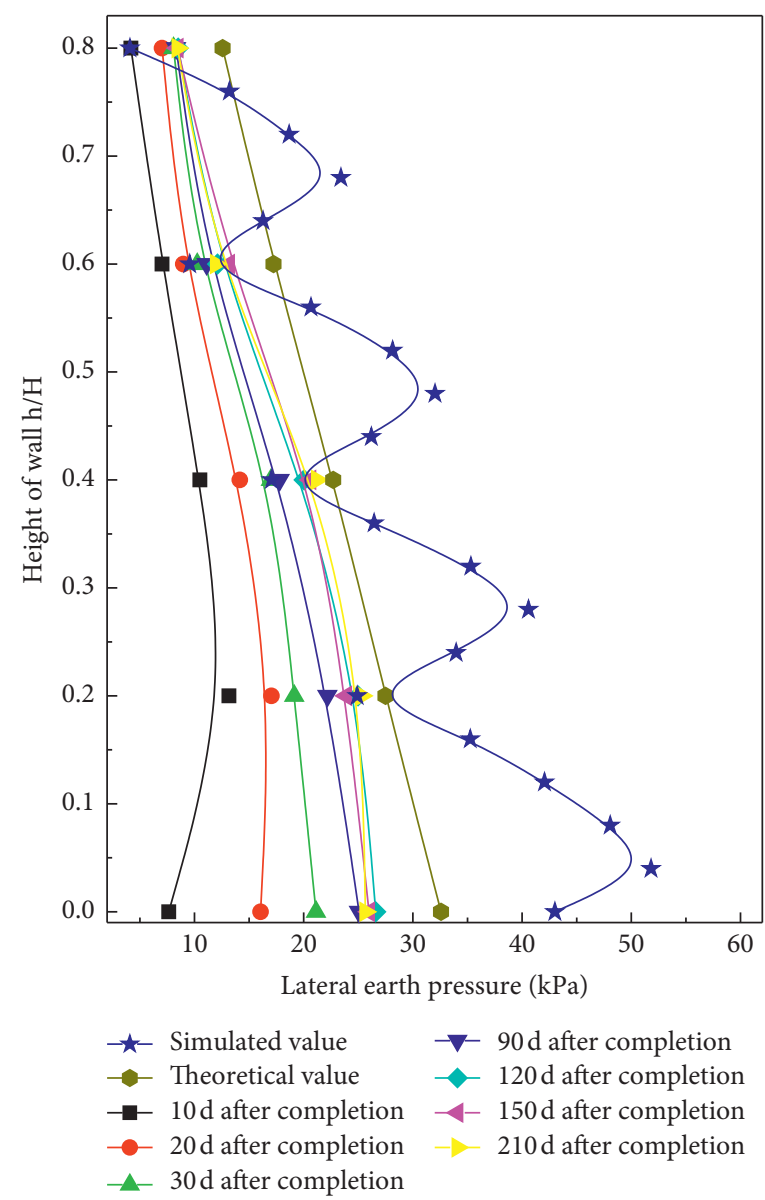

Figure 12: Variation in the lateral Earth pressure at the back of the wall (4 m away from the retaining wall surface) with completion time.

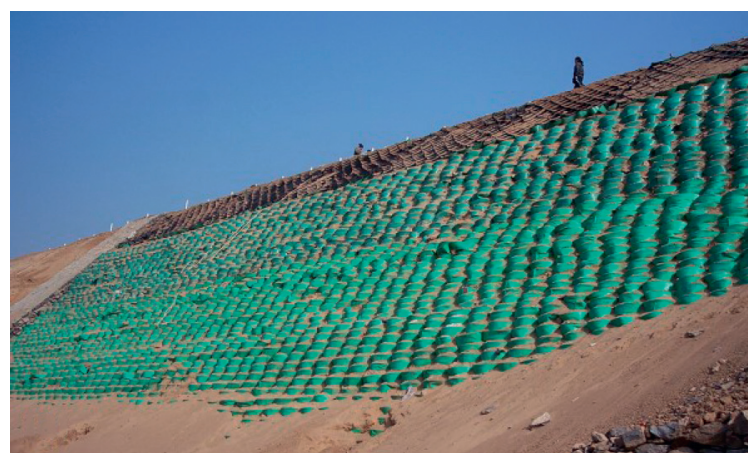

(a)

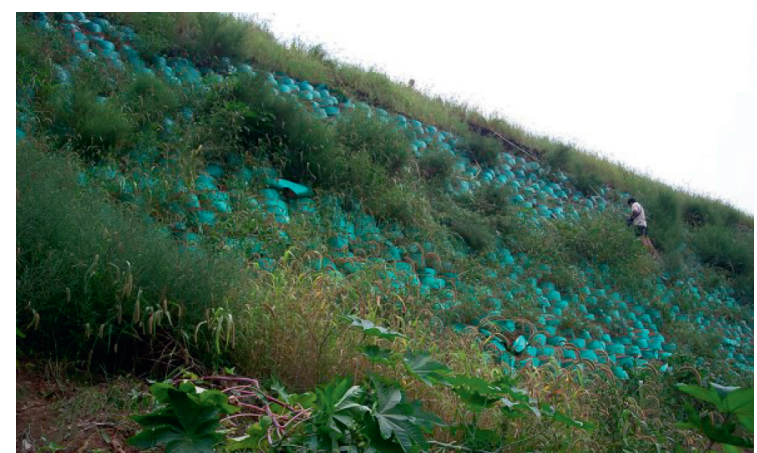

(b)

Figure 13: Application effect of flexible ecological retaining wall for slope protection. (a) After construction completion. (b) One year after completion.

Figure 13 shows the protective effect of the flexible ecological retaining wall. The flexible ecological retaining wall as a slope protection scheme for high-steep slopes is effective and practical. This case study demonstrated the effectiveness of flexible ecological retaining walls as a slope protection technology for high-steep slopes with a height of more than $15 \mathrm{~m}$; moreover, it brings significant advantages in protecting the ecological environment and improving highway landscape.

\section{Conclusions}

In this study, a flexible geocell-reinforced ecological retaining wall as a high-steep slope protection scheme was developed and applied to a portion of the Ji-Lai Expressway by analyzing the reinforcement mechanism of the geocell used. The lateral displacement and Earth pressure distribution on the flexible ecological retaining wall applied to the high-steep slope were studied using theoretical calculations 
and a finite element numerical simulation and verified using field experiments. After a detailed analysis of the results, our main findings are outlined as follows:

(1) The simulated horizontal displacement is maximum approximately $1 / 3 \mathrm{H}$ away from the wall toe, while the measured displacement is maximum $2 / 3 \mathrm{H}$ away from the wall toe. The deformation is maximum in the middle and upper parts, and the maximum measured horizontal displacement does not exceed $42 \mathrm{~mm}$.

(2) With the increase in the distance from the retaining wall surface, the lateral Earth pressure along the height of the retaining wall presents more fluctuations. The measured value at the back of the wall is lower than that at the middle of the wall.

(3) The measured value in the middle and upper parts is in good agreement with the simulated value; however, there are big differences between the measured and simulated values at the lower part of the retaining wall. This indicates that the complexity of the actual construction environment makes it difficult to evaluate the numerical parameters.

(4) The lateral Earth pressure is maximum approximately $1 / 3 \mathrm{H}$ away from the wall toe. The measured lateral Earth pressure is less than the theoretical value of the active Rankine pressure. The geocell-reinforced slope protection technology is an effective method to retain slope stability.

(5) Soil consolidation is stable, and the mechanical properties of each part of the soil tend to be uniform six months after construction. The proposed approach brings significant advantages in protecting the ecological environment and improving highway landscape.

(6) Relatively speaking, the finite element simulation result was not the same as actual value due to the complexity of actual construction progress. Therefore, adequate and effective field survey and intensive structure division should be suggested to further consider in similar future studies.

\section{Data Availability}

The data used to support the findings of this study are available from the corresponding author upon request.

\section{Conflicts of Interest}

The authors declare that there are no conflicts of interest regarding the publication of this paper.

\section{Acknowledgments}

The authors would like to express their sincere gratitude for the funding support provided by the Science and Technology Plan of Education Department of Shandong Province (J07YA05) and Research Project Grant of Shandong HiSpeed Company Limited.

\section{References}

[1] A. Pain, Q. Chen, S. Nimbalkar, and Y. Zhou, "Evaluation of seismic passive earth pressure of inclined rigid retaining wall considering soil arching effect," Soil Dynamics and Earthquake Engineering, vol. 100, pp. 286-295, 2017.

[2] O. Detert and P. Fantini, "High geogrid-reinforced slopes as flexible solution for problematic steep terrain: Triebensunk project," in Advancing Culture of Living with Landslides, M. Mikoš, Ž. Arbanas, Y. Yin et al.,(Eds), Springer, Cham, Switzerland, 2017.

[3] A.-S. Colas, J.-C. Morel, and D. Garnier, "Full-scale field trials to assess dry-stone retaining wall stability," Engineering Structures, vol. 32, no. 5, pp. 1215-1222, 2010.

[4] C.-S. Choi, S.-S. Ha, L.-H. Lee, Y.-H. Oh, and H.-D. Yun, "Evaluation of deformation capacity for RC T-shaped cantilever walls," Journal of Earthquake Engineering, vol. 8, no. 3, pp. 397-414, 2004.

[5] N. M. Saim and A. Kasa, "Numerical analysis on the effect of geometry parameter on the behaviour of the T-shaped cantilever retaining wall," in Proceedings of the Regional Conference on Science, Technology and Social Sciences (RCSTSS 2016), Springer, Singapore, pp. 393-402, 2018.

[6] H.-w. Zhu, L.-k. Yao, and J. Li, "Influence factors on the seismic behavior and deformation modes of gravity retaining walls," Journal of Mountain Science, vol. 16, no. 1, pp. 168-178, 2019.

[7] J. Liu, D. Huang, C. Yang, and S. Sun, "Upper bound seismic rotational stability analysis of gravity retaining walls considering embedment depth," Journal of Central South University, vol. 22, no. 10, pp. 4083-4089, 2015.

[8] G.-L. Li, T.-h. Zheng, Y. Fu, B.-Q. Li, and T. Zhang, "Soil detachment and transport under the combined action of rainfall and runoff energy on shallow overland flow," Journal of Mountain Science, vol. 14, no. 7, pp. 1373-1383, 2017.

[9] M. Schwarz, F. Preti, F. Giadrossich, P. Lehmann, and D. Or, "Quantifying the role of vegetation in slope stability: a case study in Tuscany (Italy)," Ecological Engineering, vol. 36, no. 3, pp. 285-291, 2010.

[10] L. Sanchez-Castillo, K. I. Kosugi, N. Masaoka, and T. Kubota, "Eco-morphological characteristics of fern species for slope conservation," Journal of Mountain Science, vol. 16, no. 3, pp. 504-515, 2019.

[11] G. B. Bischetti, E. A. Chiaradia, V. D'Agostino, and T. Simonato, "Quantifying the effect of brush layering on slope stability," Ecological Engineering, vol. 36, no. 3, pp. 258-264, 2010.

[12] Z.-x. Yan, Z.-h. Ren, C.-m. Yan, P. Jiang, and H.-y. Wang, "Study on original ecological tridimensional slope vegetation," Journal of Mountain Science, vol. 10, no. 6, pp. 932-939, 2013.

[13] S. Cao, C. Xu, H. Ye, Y. Zhan, and C. Gong, “The use of air bricks for planting roadside vegetation: a new technique to improve landscaping of steep roadsides in China's hubei province," Ecological Engineering, vol. 36, no. 5, pp. 697-702, 2010.

[14] Y. Xie and X. Yang, "Characteristics of a new-type geocell flexible retaining wall," Journal of Materials in Civil Engineering, vol. 21, no. 4, pp. 171-175, 2009.

[15] D. Liu, X. Yang, and Z. Mao, "Research on the effect of geocell in slope reinforcement using anti-slide pile with geocell," in Proceedings of the 2013 Fourth International Conference On Digital Manufacturing \& Automation, IEEE, Qingdao, China, pp. 1130-1132, 2013. 
[16] N. R. Krishnaswamy, K. Rajagopal, and G. Madhavi Latha, "Model studies on geocell supported embankments constructed over a soft clay foundation," Geotechnical Testing Journal, vol. 23, no. 2, pp. 45-54, 2000.

[17] A. Hegde and T. G. Sitharam, "Experimental and numerical studies on footings supported on geocell reinforced sand and clay beds," International Journal of Geotechnical Engineering, vol. 7, no. 4, pp. 346-354, 2013.

[18] S. K. Pokharel, J. Han, D. Leshchinsky, R. L. Parsons, and I. Halahmi, "Investigation of factors influencing behavior of single geocell-reinforced bases under static loading," Geotextiles and Geomembranes, vol. 28, no. 6, pp. 570-578, 2010.

[19] R. H. Chen and Y. M. Chiu, "Model tests of geocell retaining structures," Geotextiles and Geomembranes, vol. 26, no. 1, pp. 56-70, 2008.

[20] D. Leshchinsky, H. I. Ling, J.-P. Wang, A. Rosen, and Y. Mohri, "Equivalent seismic coefficient in geocell retention systems," Geotextiles and Geomembranes, vol. 27, no. 1, pp. 9-18, 2009.

[21] F. Song, Y.-L. Xie, Y.-F. Yang, and X.-H. Yang, "Analysis of failure of flexible geocell-reinforced retaining walls in the centrifuge," Geosynthetics International, vol. 21, no. 6, pp. 342-351, 2014.

[22] Code of China, JTG D30-2004 Specifications for Design of Highway Subgrades, Beijing, China, 2004.

[23] D. J. Henkel and G. D. Gilbert, "The effect measured of the rubber membrane on the triaxial compression strength of clay samples," Géotechnique, vol. 3, no. 1, pp. 20-29, 1952.

[24] S. K. Dash, "Influence of relative density of soil on performance of geocell-reinforced sand foundations," Journal of Materials in Civil Engineering, vol. 22, no. 5, pp. 533-538, 2010.

[25] A. Biswas and A. M. Krishna, "Geocell-reinforced foundation systems: a critical review," International Journal of Geosynthetics Ground Engineering, vol. 3, no. 2, p. 17, 2017.

[26] K. Rajagopal, N. R. Krishnaswamy, and G. Madhavi Latha, "Behaviour of sand confined with single and multiple geocells," Geotextiles and Geomembranes, vol. 17, no. 3, pp. 171-184, 1999.

[27] A. Biswas, A. M. Krishna, and S. K. Dash, "Behavior of geosynthetic reinforced soil foundation systems supported on stiff clay subgrade," International Journal of Geomechanics, vol. 16, no. 5, Article ID 04016007, 2016.

[28] L. Zhang, M. Zhao, C. Shi, and H. Zhao, "Bearing capacity of geocell reinforcement in embankment engineering," Geotextiles and Geomembranes, vol. 28, no. 5, pp. 475-482, 2010.

[29] Code of China, JTG E40-2007 Test Methods of Soils for Highway Engineering, Beijing, China, 2007.

[30] R.-H. Chen, Y.-W. Huang, and F.-C. Huang, "Confinement effect of geocells on sand samples under triaxial compression," Geotextiles and Geomembranes, vol. 37, no. 3, pp. 35-44, 2013.

[31] R. J. Bathurst and R. Karpurapu, "Large-scale triaxial compression testing of geocell-reinforced granular soils," Geotechnical Testing Journal, vol. 16, no. 3, pp. 296-303, 1993.

[32] G. Madhavi Latha, K. Rajagopal, and N. R. Krishnaswamy, "Experimental and theoretical investigations on geocellsupported embankments," International Journal of Geomechanics, vol. 6, no. 1, pp. 30-35, 2006.

[33] G. Madhavi Latha and K. Rajagopal, "Parametric finite element analyses of geocell-supported embankments," Canadian Geotechnical Journal, vol. 44, no. 8, pp. 917-927, 2007.

[34] I. Mehdipour, M. Ghazavi, and R. Z. Moayed, "Numerical study on stability analysis of geocell reinforced slopes by considering the bending effect," Geotextiles and Geomembranes, vol. 37, no. 2, pp. 23-34, 2013.

[35] F. Song, H. Liu, L. Ma, and H. Hu, "Numerical analysis of geocell-reinforced retaining wall failure modes," Geotextiles and Geomembranes, vol. 46, no. 3, pp. 284-296, 2018.

[36] F. Ren, C. Xu, Q. Xu, and G. Wang, "Finite element analysis on the mechanics behavior of super-high reinforced earth embankment in mountainous areas," Journal of Yangtze River Scientific Research Institute, vol. 31, no. 3, pp. 101-105, 2014.

[37] R.-H. Chen, C.-P. Wu, F.-C. Huang, and C.-W. Shen, "Numerical analysis of geocell-reinforced retaining structures," Geotextiles and Geomembranes, vol. 39, no. 8, pp. 51-62, 2013.

[38] K. Yang and C. Liu, "Finite element analysis of earth pressures for narrow retaining walls," Journal of GeoEngineering, vol. 2, no. 2, pp. 43-52, 2007.

[39] C. M. Zheng, W. S. Zhu, and G. F. Sun, "The application of the least square method in back analysis of 3D initial geostress," in Proceedings of the International Conference on Artificial Intelligence \& Computational Intelligence, vol. 4, IEEE, Shanghai, China, pp. 603-607, 2009.

[40] Z. Ou, C. X. Chen, H. Fu, and Y. C. Zhou, "Study on the value range of horizontal ground stress in initial geostress field based on the generalized hoek-brown criterion," Applied Mechanics and Materials, vol. 580-583, pp. 334-337, 2014. 